\title{
Evaluation of functional and pasting properties of instant pounded yam/plantain flour
}

\begin{abstract}
This study is aimed at investigating the functional and pasting properties of instant pounded yam flour supplemented by unripe plantain flour to produce instant poundo-plantain flour. White yam (Dioscorea rotundata) and unripe plantain (Musa paradisiaca) were sorted, peeled, sliced, washed, blanched and oven dried at 70 ${ }^{\circ} \mathrm{C}$ for $6 \mathrm{hr}$ and milled into flour. Blends of instant pounded yam and plantain flour were prepared at three mixing levels of 50:50 (unripe plantain flour and yam flour), 70: 30 (unripe plantain flour and pounded yam flour), 70: 30 (pounded yam flour and unripe plantain flour) while $100 \%$ pounded yam flour and $100 \%$ plantain flour were used as controls. The functional and pasting properties were determined using standard analytical methods and all the data obtained were subjected to one way analysis of variance. Results showed a significant difference $(p<0.05)$ in the emulsion capacity of the composite plantain and pounded yam flour samples ranging from 2.20 to $4.17 \%$ with the highest value recorded in sample $\mathrm{C}$ ( $50 \%$ poundo yam and $50 \%$ plantain flour) and the least value in E (30\% plantain and 70\% poundo yam flour). Sample A (100\% pounded yam flour) showed a significant highest foam capacity of $7.10 \mathrm{ml} / \mathrm{g})$ than all other samples, and sample B $(100 \%$ plantain flour $)$ showed a least foaming capacity $(2.03 \mathrm{ml} / \mathrm{g})$. The water absorption capacity (WAC) of composite plantain and pounded yam flours differed significantly $(\mathrm{p}<0.05)$ and it ranged from 2.03to $4.13(\mathrm{ml})$ with Sample B having the highest WAC $(4.13 \mathrm{ml} / \mathrm{g})$ and sample A the lowest score $(2.03 \mathrm{ml} / \mathrm{g})$. Sample B recorded the oil absorption capacity $(1.59 \mathrm{mls})$ and was significantly different from other samples while sample $C$ had the lowest value $(0.93 \mathrm{mls})$. Sample B $(100 \%$ plantain flour $)$ had a significantly $(\mathrm{p}>0.05)$ higher swelling capacity than the sample A ( $100 \%$ pounded yam flour).The peak viscosity of the composite plantain and pounded yam flours ranged from 915-1789 (BU) with sample A having significantly higher value than sample B. A final viscosity ranging from $1409-2430 \mathrm{BU}$ was observed for the flour samples with the highest value in sample A and least value in sample B. The trough values ranged from $842-1688 \mathrm{BU}$ with the highest value in sample A and least value observed in sample B. The pasting temperature of composite plantain and pounded yam flours varied between 84.00 $87.27^{\circ} \mathrm{C}$ with the highest value in sample B and lowest value recorded in sample A. However, the peak time for all the flour samples remains unchanged $(7.00 \mathrm{~min})$.
\end{abstract}

Keywords: Yam, plantain, instant pounded plantain/yam flour, functional properties, pasting properties

\section{Introduction}

Plantain (Musa paradisiaca) is an important staple crop that contributes to the calories and subsistence economies in Africa. They are good sources of carbohydrate, (Marriott et.al., 1981). Plantain cultivation is attractive to farmers due to low labour requirements for production compared with cassava, maize, rice and yam (Marriott and Lancaster, 1983). Musa paradisiaca are important starchy staple and commercial crop in West and Central Africa where $50 \%$ of the world plantain crop is produced. ${ }^{1}$ In Nigeria, plantains and bananas are both important staples and are sources of income for subsistence farm families. There has been increasing trend towards large scale production of the crop. ${ }^{2}$ They contribute significantly to food security and provide more than $25 \%$ and $10 \%$ of the daily intake of carbohydrate and calories, respectively, for more than 70 million people in sub Saharan Africa. ${ }^{3}$ In Nigeria, plantain production was estimated at $2,722.000$ metric tons in 2009, with an average consumption level of $190 \mathrm{~kg} /$ person/year (FAO, 2011). However about 35- 60\% postharvest loss was reported. ${ }^{4}$ This means that these surpluses have to be exported or processed (Dankye et al., 2007). Hence the need to process them into shelf stable forms that will be made available all the year round.
Volume 9 Issue I - 2019

\author{
Olumurewa JAV,' Ibidapo PO, ${ }^{2}$ Adebileje J $\mathrm{F}^{\prime}$ \\ 'Department of Food Science \& Technology, Federal University \\ of Technology, Nigeria \\ 2Department of Food \&Analytical, Federal Institute of Industrial \\ Research Oshodi, Nigeria
}

Correspondence: Adebileje JF, Department of Food Science \&
Technology, Federal University of Technology, P M B 704,Akure Ondo State, Nigeria, Email jav_murewa@yahoo.com

Received: October 26, 2018| Published: January 28, 2019 especially to manage type 2 diabetes. Results from metabolic studies have suggested that carbohydrate with high glycemic index (a qualitative indicator of carbohydrate ability to raise blood glucose levels) increase insulin demand and heighten hyper insulinemia. ${ }^{5-7}$ Yam (Dioscorea species) is an important tropical root crop. It ranked as the fourth major root crop in the world after cassava, potatoes and sweet potatoes (Adeleke, 2010). It is also an important source of carbohydrate for many people of the Sub-Sahara region, especially in the yam zone of West Africa. ${ }^{8}$ Nigeria is the world largest producer of edible yam with D.rotundata and D. alata as the two most cultivated yam species in the country. It was reported that yam contributes more than 200 dietary calories per capital daily for more than 150 million people in West Africa and serves as an important source of income to the people (Babaleye, 2003). Yams are characterized by high moisture content, which renders the tubers more susceptible to microbial attacks and brings about high perish ability of the tubers (FOS, 2011). Nutritionally, yam constitutes a significant carbohydrate and fiber food sources. Others nutrient present in yam are caloric proteins, minerals and vitamins. The crop is important in household food security, diet diversification, employment and income generation 
as well as alleviation of poverty. ${ }^{8}$ Industrial processing and utilization of yam includes starch, poultry and livestock feed, production of yam flour and instant pounded yam flour production. Traditionally, the processing of pounded yam using pestle and mortar is highly valued but it is generally being replaced in the market with the instant pounded yam flour. Instant pounded yam flour requires short processing time and less energy (Akinoso and Olatoye, 2013). Poundo yam which is referred to as instant pounded yam flour (IPYF) is a processed white powdery form of yam (dehydrated yam flour) which is produced in a desiccating machine ${ }^{9}$ It is a fast means of making pounded yam which is done by pouring a measured quality of the yam flour into boiling water, which is stirred continuously until the required texture and taste is achieved (Ayodeji et al., 2012). The basic processing technology of yam includes peeling, washing, slicing/dicing, cooking, drying, milling, and packaging.

Unripe plantain is rich in resistant starches which are intrinsically resistant to digestion before cooking. The importance of resistant starches in a food is that it resist digestion and in many ways behaves like fiber which have physiological effects, both for digestive functions such as constipation, digestive cancer, cholesterolemia and glycemia ${ }^{10}$ and have ability to regulate blood glucose levels which consequently helps in management and prevention of certain chronic diseases such as diabetes and obesity. This study is thus geared toward substituting yam flour with plantain flour in order to reduce the associated diseases of pounded yam eating predominant society.

\section{Materials and methods}

The raw materials used for this study include; white yam and unripe plantain

\section{Sources of raw materials}

Unripe plantain and white yam were obtained from Mushin Market, Lagos state, Nigeria.

\section{Sample preparation}

Preparation of unripe plantain flour: The unripe plantain was processed to flour according to the modified method of Ogazi. ${ }^{3}$ It was peeled, sliced, washed with water parboiled and dried in forced air oven at $70^{\circ} \mathrm{C}$ to a moisture content of less than $10 \%$. It was then milled using hammer mill and packaged in high density polyethylene bag for further analysis (Figure 1) (Figure 2)

Preparation of instant pounded yam flour: The instant pounded yam flour was processed to flour. It was peeled, sliced, washed with water and parboiled and dried in forced air oven at $70^{\circ} \mathrm{C}$ until three consecutive constant weights was obtained; with final moisture content of $8.5 \%$. It was then milled using hammer mill and packaged in high density polyethylene bag for further analysis

Formulations of samples: The instant plantain flour and instant pounded yam flour were mixed in varying proportions to obtain five different formulations. The proportions were obtained from slight modifications of previous research studies. The samples were packaged in a high density polyethylene bag for further analysis.

\section{Determination of functional properties of flour blends}

Emulsion capacity: Emulsion capacity was determined according to the method described by AOAC. ${ }^{11}$ About $2 \mathrm{~g}$ of flour sample and distilled water $(100 \mathrm{ml})$ were blended for 30 secs at high speed (1000rpm) after complete dispersion, peanut oil was added from a burette in streams of about $5 \mathrm{ml}$. blending continued until there appeared separation into two distinct layers (emulsion break point). Emulsion capacity was expressed as grams of oil emulsified by $1 \mathrm{~g}$ flour. Duplicate measurements were made and average results taken.

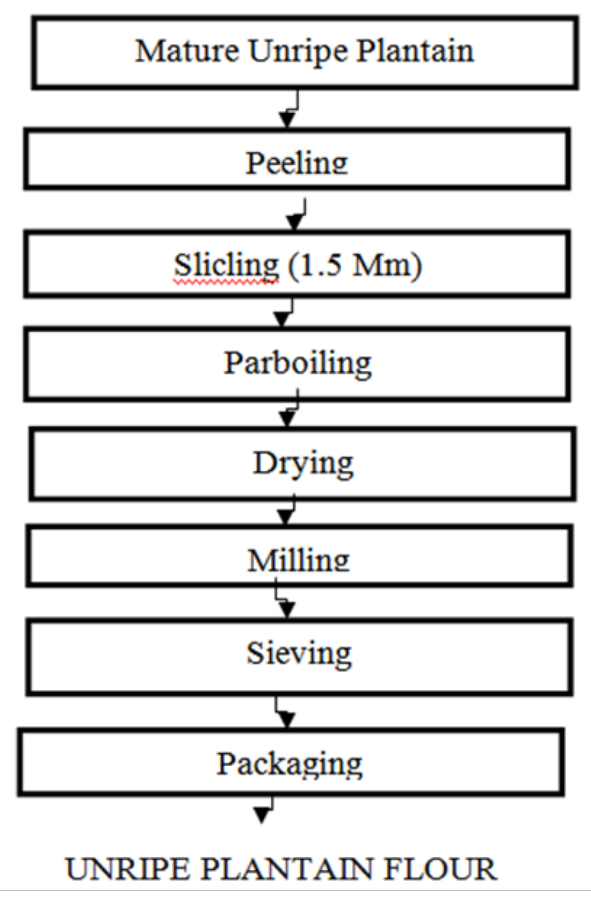

Figure I Flowchart for the production of unripe plantain flour.

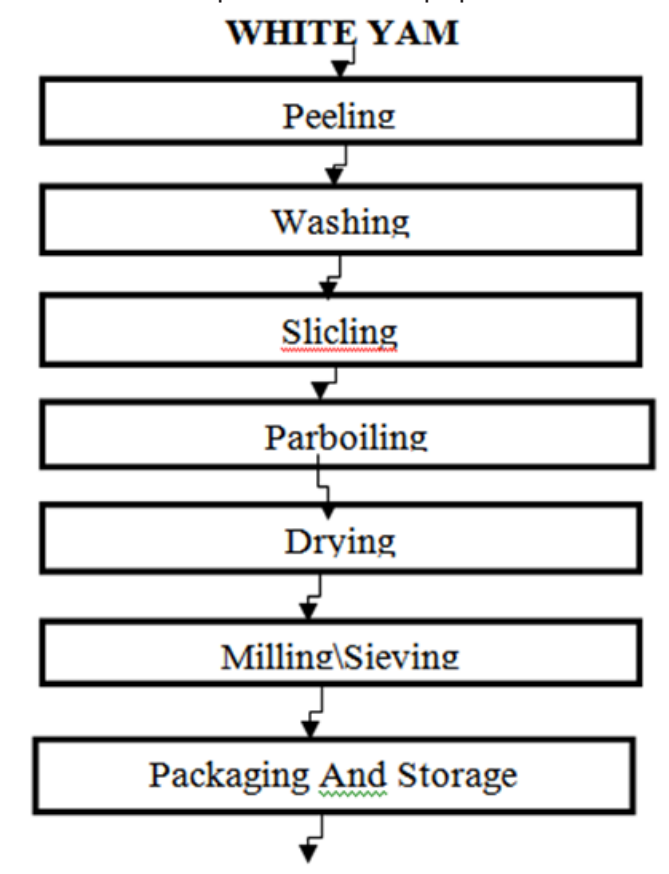

INSTANT POUNDED YAM FLOUR

Figure 2 Flowchart for Production of Instant Pounded Yam flour.

Swelling capacity: About $0.1 \mathrm{~g}$ sample is heated in $10 \mathrm{ml}$ distilled water in a water bath at 50,70 and $90^{\circ} \mathrm{C}$ for 30 minutes respectively with constant mixing. The samples were centrifuged at $1600 \mathrm{rpm}$ for 
15 minutes. The precipitated part was weighted and calculated using equation (1).

$$
\text { Swellingpower }=\frac{\text { weightofsedimentpaste }(g)}{\text { weightofdrysample }(\text { drybasis })(g)}
$$

\section{Water absorption of capacities}

Distilled water $(10 \mathrm{ml})$ was added to $1 \mathrm{~g}$ of the starch sample in a weighed $25 \mathrm{ml}$ centrifuge tube. The tube was agitated on a vortex mixer for $2 \mathrm{~min}$, and then centrifuged at $1250 \times \mathrm{g}$ for 20 minutes. The clear supernatant was decanted and weighed. The adhering drops of water was removed and reweighed. Water absorption capacity (WAC) is expressed as the amount of water absorbed by $1 \mathrm{~g}$ dried starch sample.

\section{Oil absorption capacity}

About $1 \mathrm{~g}$ of the composite flour samples were mixed with $20 \mathrm{ml}$ of oil in a blender at high speed for about $30 \mathrm{sec}$. samples were allowed to stand at $30^{\circ} \mathrm{C}$ for $30 \mathrm{~min}$ and then centrifuged at $1000 \mathrm{rpm}$ for 30minutes. The volume of supernatant in a graduated cylinder was noted. Density of water was taken to be $1 \mathrm{~g} / \mathrm{ml}$ and that of oil determined to be $0.93 \mathrm{~g} / \mathrm{ml}$. Means of the triplicate determinations were reported.

Foaming capacity: The method described by Onwuka ${ }^{12}$ was adopted. Two grams $(2 \mathrm{~g})$ of each sample were blended with $100 \mathrm{ml}$ of distilled water in a warring blender and the suspension was whipped at $1600 \mathrm{rpm}$ (revolution per minutes) for $5 \mathrm{~min}$ at room temperature. The mixture was quickly transferred to a $250 \mathrm{ml}$ measuring cylinder and the foam volume was measured after 30 seconds. Foam capacity was expressed as percentage increase in volume thus:

$$
\begin{aligned}
& \text { Foamingcapacity }=\frac{\text { Volume after Whipping }- \text { Volume before Whipping }}{\text { Volume before Whipping }} \times 100 \\
& \text { Pasting properties }
\end{aligned}
$$

Pasting characteristics of the samples were determined by the use of Rapid Visco Analyzer (RVA Model, Newport Scientific Pty. Ltd., Sydney, Australia, 1994). 3.5g (dry weight) of each of the samples was weighed into the RVA canister, and $25 \mathrm{ml}$ of distilled water was added. The paddle was placed into the canister containing the sample and water. The paddle blade was vigorously jogged through the sample up and down seven times. The sample was then inserted in the RVA. The slurry was heated from $50^{\circ} \mathrm{C}$ to $95^{\circ} \mathrm{C}$ with a holding time of $2 \mathrm{~min}$ followed by cooling to $50^{\circ} \mathrm{C}$ with holding time of $2 \mathrm{~min}$. The parameters recorded from the pasting profile were Peak viscosity $(\mathrm{PV})$, trough (TV), breakdown viscosity $(\mathrm{BV}=\mathrm{PV}-\mathrm{TV})$, Final viscosity (FV), setback viscosity (SV=FV- TV) and Pasting temperature. This was carried out in duplicate and repeated for all samples.

\section{Data analysis}

One way analysis of variance (ANOVA) was conducted to establish the significance difference between the means, which were separated using Duncan Multiple Range Test (DMRT).

\section{Results and discussion}

\section{Functional properties of composite plantain and pounded yam flours}

The functional properties determine the applications and uses of food materials for various food products. ${ }^{13}$ The results for functional properties of composite plantain and poundo yam flours are shown in Table 1 . The values for emulsion capacity of the composite plantain and poundo yam flours ranged from $2.20 \%$ to $4.17 \%$. There were significant differences $(\mathrm{p}<0.05)$ between the samples with significant reduction $(\mathrm{p}<0.05)$ observed in the blends containing plantain flour, however the blends containing $30 \%$ had the least emulsion capacity while the highest value was observed in $100 \%$ poundo yam flour . This may be due to the varying protein contents of the samples as protein has a role to play in the determination of emulsion capacity. ${ }^{14}$ Foam capacity of the composite plantain and poundo yam flours ranged from $2.03 \mathrm{ml}$ to $7.10 \mathrm{ml}$ in samples B and A respectively. There was also significant difference between all the sample of composite plantain and poundo yam flours in relation to their foam capacity. KiintoKabari et al., ${ }^{14}$ reported that foaming increased progressively with increase in protein concentrates of wheat / plantain flour enriched with bambara groundnut protein concentrate. Foam capacity of protein can be referred to as the amount of interfacial area that can be created by the protein and foam is a colloidal of many gas bubbles trapped in a liquid or solid while the small air bubbles are surrounded by thin liquid films. ${ }^{15}$ Swelling capacity measures the hydration capacity of the flour blends because it determines the extent to which a flour sample increases in volume when soaked in water in relation to its initial volume. The swelling capacity at $65^{\circ} \mathrm{C}$ of the composite plantain and pounded yam flours ranged from 8.05 to $10.05(\mathrm{~g} / \mathrm{g})$, from Table 2. Results showed that samples A (100\% instant pounded yam flour) had the lowest value and highest value was obtained for sample B (100\% instant plantain flour) respectively. $100 \%$ plantain flour had a significantly $(p>0.05)$ higher swelling capacity than the $100 \%$ pondo yam flour. The swelling capacity of the flour blends increased with increasing level of plantain flour. The water absorption capacity describes how the flour blends associate with limited amount of water. The water absorption capacity of composite plantain and pounded yam flours differed significantly $(\mathrm{p}>0.05)$ and it ranged from 2.03 $4.13 \mathrm{ml} / \mathrm{g}$ with the highest value in $100 \%$ plantain flour and least value in $100 \%$ pondo yam flour however, the water absorption capacity increased with increasing level of plantain flour supplementation. This variation may be attributed to the different starch granules of the plantain and yam flours and to the presence of greater amount of hydrophilic constituents like soluble fiber and lower amount of fat content in plantain flour. ${ }^{16}$ Oil absorption capacity differed significantly $(\mathrm{p}>0.05)$ among the flour samples. It ranged from 0.93 $1.59 \mathrm{ml} / \mathrm{g}$ with the highest value in sample B (100\% plantain flour) while the lowest value was observed in sample $\mathrm{C}(50 \%$ pondo yam and $50 \%$ plantain) flour blends. Resulted indicated that plantain flour substitution increased the oil absorption capacity. Absorption of oil by food products improves mouth feel and flavor retention of a product. ${ }^{17}$ High oil absorption capacity could suggest the presence of a large proportion of hydrophobic groups as compared with the hydrophilic groups on the surface of protein molecules (Subagio, 2006).

\section{Pasting properties of composite plantain and pounded yam flours}

Pasting properties of composite plantain and pounded yam flours were presented on Table 3 Pasting properties shows the way starch and starch-based products behaves during heat treatment in the presence of water. There is always a clear relationship between peak viscosity, swelling power and breakdown viscosity and higher levels of amylopectin content is also associated with a higher swelling capacity. ${ }^{18}$ Pasting properties are essential for many applications of starch in the food industries, such as thickeners and sizing agents 
because they influence the texture, stability and digestibility of starchy foods. ${ }^{19}$ Peak viscosity measures the ability of starch to swell freely before their physical breakdown..$^{20}$ The peak viscosity of the composite plantain and pounded yam flours ranged from 915 to 1789 (BU) for samples B and A respectively. Increased substitution with plantain flour decreased the peak viscosity, thus the peak viscosity of sample A was significantly higher than sample B. This indicated that the water binding capacity of the starch granules of yam flour was significantly higher than plantain flour. Peak viscosity can also be referred to as the maximum viscosity developed during or soon after the heating, and it is often correlated with the final product quality and also provides an indication of the viscous loads likely to be encountered during mixing. ${ }^{14}$ The hold period (Trough) is sometimes referred to as shear thinning, holding strength or hot- paste viscosity is a period when the samples were subjected to a period of constant temperature and mechanical shear stress. ${ }^{14}$
Table I Proportion of raw materials in blended products

\begin{tabular}{lll}
\hline Codes & Yam $(\%)$ & Plantain $(\%)$ \\
\hline A & 100 & - \\
B & - & 100 \\
C & 50 & 50 \\
D & 30 & 70 \\
E & 70 & 30 \\
\hline
\end{tabular}

Key:

$A=100 \%$ Pounded Yam Flour

$\mathrm{B}=100 \%$ Plantain Flour

C $=50 \%$ Pounded Yam and $50 \%$ Plantain Flour

$\mathrm{D}=\mathbf{7 0} \%$ Plantain and $30 \%$ Pounded Yam Flour

$E=30 \%$ Plantain and $70 \%$ Pounded Yam Flour

Table 2 Functional Properties of Composite Plantain and Pounded Yam Flours

\begin{tabular}{lllllc}
\hline Samples & Emulsion $(\mathbf{m l} / \mathbf{g})$ & Foaming $(\mathbf{m l} / \mathbf{g})$ & Swelling capacity $\left(\mathbf{6 5}^{\mathbf{0}} \mathbf{c}\right)$ & OAC $(\mathbf{m l})$ & WAC $(\mathbf{m l} / \mathbf{g})$ \\
\hline A & $4.07 \mathrm{~b} \pm 0.11$ & $7.10 \mathrm{a} \pm 0.10$ & $8.05 \mathrm{e} \pm 0.03$ & $1.18 \mathrm{c} \pm 0.01$ & $2.03 \mathrm{c} \pm 0.06$ \\
B & $3.80 \mathrm{c} \pm 0.02$ & $2.03 \mathrm{~d} \pm 0.06$ & $10.05 \mathrm{a} \pm 0.03$ & $1.59 \mathrm{a} \pm 0.01$ & $4.13 \mathrm{a} \pm 0.12$ \\
C & $4.17 \mathrm{a} \pm 0.06$ & $4.03 \mathrm{c} \pm 0.06$ & $9.03 \mathrm{~b} \pm 0.03$ & $0.93 \mathrm{~d} \pm 0.12$ & $3.17 \mathrm{~b} \pm 0.15$ \\
D & $2.58 \mathrm{~d} \pm 0.03$ & $5.03 \mathrm{~b} \pm 0.06$ & $8.81 \mathrm{c} \pm 0.02$ & $1.42 \mathrm{~b} \pm 0.02$ & $4.03 \mathrm{a} \pm 0.06$ \\
E & $2.20 \mathrm{e} \pm 0.09$ & $5.03 \mathrm{~b} \pm 0.06$ & $8.11 \mathrm{~d} \pm 0.02$ & $1.17 \mathrm{c} \pm 0.06$ & $3.25 \mathrm{~b} \pm 0.06$
\end{tabular}

All the values are means and standard deviation of triplicate determination. Means within the same column having the same superscript are not significantly different at $(\mathrm{p}<0.05)$.

Key:

$A=100 \%$ Pounded Yam Flour

$\mathrm{B}=100 \%$ Plantain Flour

C $=50 \%$ Pounded Yam and $50 \%$ Plantain Flour

$\mathrm{D}=70 \%$ Plantain and $30 \%$ Pounded Yam Flour

$\mathrm{E}=30 \%$ Plantain and $70 \%$ Pounded Yam Flour

OAC = Oil Absorption Capacity

WAC $=$ Water Absorption Capacity

Table 3 Pasting Properties of Composite Plantain and Pounded Yam Flours

\begin{tabular}{|c|c|c|c|c|c|c|c|}
\hline Flour & $\begin{array}{l}\text { Peak } \\
\text { (BU) }\end{array}$ & $\begin{array}{l}\text { Trough } \\
\text { (BU) }\end{array}$ & $\begin{array}{l}\text { Breakdown } \\
\text { (BU) }\end{array}$ & $\begin{array}{l}\text { Final viscosity } \\
\text { (BU) }\end{array}$ & $\begin{array}{l}\text { Setback } \\
\text { (BU) }\end{array}$ & $\begin{array}{l}\text { Peak time } \\
\text { (min.) }\end{array}$ & $\begin{array}{l}\text { Pasting temperature } \\
\left({ }^{\circ} \mathrm{C}\right)\end{array}$ \\
\hline A & 1789 & 1688 & 101 & 2430 & 742 & 7 & 84 \\
\hline B & 915 & 842 & 73 & 1409 & 567 & 7 & 87.25 \\
\hline C & 1047 & 953 & 94 & 1586 & 633 & 7 & 85.55 \\
\hline $\mathrm{D}$ & 952 & 867 & 85 & 1482 & 615 & 7 & 85.55 \\
\hline E & 1174 & 1080 & 94 & 1740 & 660 & 7 & 83.95 \\
\hline
\end{tabular}

Key:

$A=100 \%$ Pounded Yam Flour

$\mathrm{B}=100 \%$ Plantain Flour

C $=50 \%$ Pounded Yam and $50 \%$ Plantain Flour

$\mathrm{D}=70 \%$ Plantain and $30 \%$ Pounded Yam Flour

$E=30 \%$ Plantain and $70 \%$ Pounded Yam Flour

It is an index of starch stability to heating. The trough values ranged from 842 to $1688 \mathrm{BU}$ with the highest value in sample A and least value observed in sample B. The high trough of A (1688) and $\mathrm{E}(1080 \mathrm{BU})$ indicated that the heat treatments enhanced the starch granules and made them stable to heat. High holding strength exhibited by sample A showed that the flour could withstand high heat treatment during processing than sample B. Bhattacharya et al. (1999) indicated that high holding strength generally represents

low cooking loss and superior eating quality. Breakdown viscosity is also regarded as a measure of paste stability ${ }^{14}$ and it ranged from 73 BU for sample B to 101 BU for sample A. Sample A (100\% instant poundo yam flour) had the highest breakdown viscosity value of 101 BU while $100 \%$ instant plantain flour (sample B) had the lowest breakdown viscosity value of $73 \mathrm{BU}$. It is an indication of breakdown or stability of the starch gel during cooking. Alam et al,. ${ }^{21}$ reported that higher breakdown viscosity depicted that starch granules were less 
resistant to thermal treatment while on the contrary, Beta et al (2000) reported that flour samples with low breakdown values indicated high stability. This result showed that $100 \%$ plantain flour was more stable, followed by sample D (70\% plantain flour and 30\% yam flour) which had $85 \mathrm{BU}$ than other composite flours. Breakdown viscosity is the difference between the peak viscosity and the trough viscosity. The setback viscosity of the composite plantain flour and poundo yam flour ranged from 567 to 742 (BU) for samples B and A respectively. It is the difference between the final viscosity and trough viscosity. Lower setback viscosity indicates higher potential for retro gradation in food products and gives an idea about retro gradation tendency of starch. ${ }^{22}$ From these setback values, the samples can be useful in preparation of instant pastes. ${ }^{14}$ Sample A had the highest setback viscosity which is very desirable for a gel of high rigidity and this was in agreement with the findings of Okorie et al., ${ }^{23}$ who reported that starch of lesser yam variety exhibited highest setback viscosity than two commonly consumed yam varieties studied. Also, the final viscosity (2430 BU) value of $100 \%$ poundo yam flour (sample A) indicated the ability to form a firm, viscoelastic paste or gel after cooking and cooling owing to re-association of starch molecules. ${ }^{24}$ It ranged from 1409 BU (sample B) to $2430 \mathrm{BU}$ (sample A) with the highest value in sample A and least value in $100 \%$ plantain flour (sample B). This work corroborated the finding of Jimoh \& Olatidoye ${ }^{25}$ who reported high values for yam flour and decrease in the soybean fortified yam flour samples. Pasting temperature usually is a measure of the lowest temperature needed to cook any food sample, composite flours with higher pasting temperature may not be recommended for certain products due to high cost of energy. The pasting temperature of composite plantain and poundo yam flours varied between $84.00-87.27^{\circ} \mathrm{C}$. Sample A had the lowest pasting temperature $\left(84.00^{\circ} \mathrm{C}\right)$ while sample $\mathrm{B}$ had the highest value $\left(87.27^{\circ} \mathrm{C}\right)$. This means that the pasting temperature of the flours and their composites is lower than the boiling temperature; hence the flours can form a paste in hot water below boiling point. This means that there is a remarkable energy saving at a commercial level. Also, report confirmed that pasting temperature correlated with water binding capacity and a higher pasting temperature implies higher water binding capacity property of starch due to high degree of association between starch granules. ${ }^{26}$

\section{Conclusion}

In conclusion, results from this study suggested that substituting unripe plantain flour with instant pounded yam flour would produce acceptable and nutritious instant pounded yam/plantain flour. Also, plantain flour substitution increased the oil absorption capacity and swelling capacity of the flour blends. Increased substitution with plantain flour decreased the peak, final, setback, breakdown, and trough viscosities. These implied that the composite flour samples could find applications in food systems such as baby food formulations, fufu production and bread making.

\section{Acknowledgments}

None.

\section{Conflicts of interest}

The authors declared there is no conflicts of interest.

\section{References}

1. Swennen R. Plantain Cultivation under West African Conditions. A Reference Manual. 1990. 29 p.
2. Rodriguez-Ambriz SL, Islas-Hernandez JJ, Agama-Acevedo E, et al. Characterization of a fiber-rich powder prepared by liquefaction of unripe banana flour. Food Chemistry. 2008;107(4):1515-1521.

3. Ogazi PO. Storage and processing of plantain. 1: Invited lecture at the 1983. Plantain production Training course. IITA Ibadan, Nigeria. 1983.

4. Abioye VF, Ade-Omowaye BIO, Babarinde GO, et al. Chemical, physico-chemical and sensory properties of soy-plantain flour. Afr $J$ Food Sci. 2011;5(4):176-180.

5. Jenkins DJA, Kendall CWC, Augustin LSA, et al. Glycemic index: overview of implications in health and disease. The American Journal of Clinical Nutrition. 2002;76(1):266S-273S.

6. Brand-Miller J, Hayne S, Petocz P, et al. Low-Glycemic Index Diets in the Management of Diabetes. Diabetes care. 2003;26(8):2261-2267.

7. Fontvieille AM, Rizkalla SW, Penformis A, et al. The use oflow glycaemic index foods improves metabolic control of diabetic patients over five weeks. Med. 1992;9(5):444-450.

8. Akissoé N, Hounhouigan J, Mestres C, et al. How blanching and drying affect the colour and functional characteristics of yam (Dioscorea cayenensis-rotundata) flour. Food Chem. 2003;82(2):257-264.

9. Olaoye JO, Oyewole SN. Optimization of some "poundo" yam production parameters. Agriculture Engineering International: CIGR Journal. 2012;14(2):58-67.

10. Lairon D, Arnault N, Bertrais S. Dietary Fiber intake and risk factors for cardiovascular disease in French adults. Am J Clin Nutr. 2005;82(6):1185-1194.

11. Official Methods of Analysis. In: Horowitz W, editor. 18th ed. USA: AOAC; 2005.

12. Onwuka GI. Functional properties in Food analysis and instrumentation. Naphtali Prints Lagos. 2006. p. 134-135.

13. Adegunwa MO, Adebowale AA, Bakare HA, et al. Compositional characteristics and functional properties of instant plantaintobreadfruit flour. International Journal of Food Research. 2014;1:1-7.

14. Kiinto Kabari DB, Eketo Ejiofor J, Giami SY. Functional and PastingProperties of Wheat/Plantain Flours Enriched with Bambara Groundnut Protein Concentrate. International Journal of Food Science and Nutrition Engineering. 2015;5(2):75-81.

15. Chandra S, Singh S, Kumari D. Evaluation of functional properties of composite flours and sensorial attributes of composite flour biscuits. Journal of Food Science and Technology. 2015;52(6):3681-3688.

16. Akubor PI, Badifu GIO. Chemical composition, functional properties andbaking potential of African bread fruit kernel and wheat flour blends. International Journal of Food Science and Technology. 2004;39(2):223-229.

17. Yadav RB, Yadav BS, Dhull N. Effect of incorporation of plantain and chickpea flours on the quality characteristics of biscuits. Journal of Food Science and Technology. 2012;49(2):207-213.

18. Ashogbon AO. Physicochemical properties of bambarra groundnut starch and cassava starch blends. African Journal of Food Science. 2014;8(6):322-329.

19. Oke MO, Awonorin SO, Workneh TS. Effect of varieties on physicochemical and pasting characteristics of water yam flours and starches. Afr J Biotechnol. 2013;12(11):1250-1256.

20. Awolu OO, Olofinlae SJ. Physicochemical, functional and pasting properties of native and chemically modified water yam (Dioscoreaalata) starch and production of water yam starch to based yoghurt. Starch/ Stärke. 2016;68:1-8. 
21. Alam F, Siddiqui A, Lutfi Z, et al. Effect of different hydrocolloids on gelatinization behavior of hard wheat flour. Trakia J Sc. 2009; 7(1):1-6.

22. Oduro I, Ellis WO, Argyectry SK, et al. Pasting characteristics of starch from varieties of sweet Potato. Tropical Science. 2000;40(1):25-28.

23. Okorie PA, Okoli EC, Ndie EC. Functional and Pasting Properties of Lesser Known Nigerian Yams as a Function of Blanching Time and Particle Size. Advance Journal of Food Science and Technology. 2011;3(6):404-409.
24. Newport Scientific Applications manual for the Rapid visco analyzer using thermocline for windows. Australia: Warriewood NSW; 1998. p. 226.

25. Jimoh KO, Olatidoye OP. Evaluation of Physicochemical and Rheological Characteristics of Soybean Fortified Yam Flour. Journal of Applied Biosciences. 2009;13:703-706.

26. Kulkani KD, Kulkani DN, Ingle UM. Sorghum malt-based weaning food formulations: Properties, functional properties, nutritive value. Food Nutr Bull. 1991;13:322-329. 